\title{
The Performance of Employees Who Works at Foreign Banks in Indonesia
}

\author{
Willy Arafah ${ }^{1}$ \\ ${ }^{1}$ Department of Management (FEB), University of Trisakti, Jakarta, Indonesia \\ Correspondence: Willy Arafah, Department of Management (FEB), University of Trisakti, Jakarta, Indonesia.
}

Received: July 25, 2017

doi:10.5539/ibr.v10n9p172

\begin{abstract}
The purpose of this reserach is to discuss the performance of foreign banking in Indonesia, including the performance of onshore and offshore banking activities, and local security devices. Although the offshore business of foreign banks has been relatively more active over the years than the onshore business, there has been a recent sharp increase in onshore business, and some indication of a more sympathetic attitude to onshore foreign banking by the regulatory authorities. This suggests that it is an appropriate time for surveying the foreign bank performance of Indonesia. Indonesia's banks still achieve the highest margins among their regional peers, maintaining their allure for investors, despite the headwinds and occasional crises they have faced in recent and perhaps upcoming years. Indonesia, the largest economy in Southeast Asia is more attractive compared to its neighbors. This study aims to determine the factors that affect the performance of employees working at foreign banks in Indonesia, this study was conducted in 2017, The research question lies in whether each of those factors has a simultaneous and partial effect on the employees performance or otherwise. Using the quantitative method, the population of this study was 550 respondents employees of foreign banks at the level of staff until the director with $\mathrm{N}=1565$. The results in this study are servant leadership employee engagement and organizational citizenship behavior greatly affect job performance.
\end{abstract}

Keywords: employee engagement, job performance, organizational citizenship behavior, servant leadership

\section{Introduction}

Infrastructure development in indonesia currently requires a lot of cost, therefore the role of foreign banks is expected to contribute to the development of Indonesia at this time, especially to improve the economic growth of Indonesia. Good service in a banking will provide satisfaction to the customer itself, as well as the quality of products offered by the bank to its customers who provide many benefits in every transaction activity. Therefore a banking must pay attention to the problem of customer satisfaction. Because in creating customer satisfaction against a company is not easy. Quality of service and quality of this product is reflected from the customer satisfaction to re-use banking services. Customer satisfaction in using services or products offered can be used as input for the management to improve and improve the quality of service as well as the quality of products provided.

For that employees who works on the service should always monitor the feeling of satisfaction by banking customers. Paying attention to customer needs and winning competition from competitors requires a strategy, the goal is to create deep brand image for users of products and services. Customer satisfaction is a strategic target for companies to grow and grow and still exist in the face of very tight competition changes. Based on background and problem identification can be formulated problem in this research are: (1). does servant leadership affect job performance? (2). does employee engagement affect job performance? (3). does the organizational citizenship behavior affect job performance?

\section{Literature Review}

\subsection{Servant Leadership}

In theory proposed by Membe and Engelbrecht (2013) identifies leadership as an important part to encourage employee engagement, team effectiveness, and organizational success. According Patterson (2003) servant leadership provides vision, empowerment, and service as the main activities of a leader. Whetston (2002) and Wong \& Page (2003) stated that servant leadership refers to ethics. Sarros \& Santora (2008) and Spears (2010) 
use the rationale that service to the follower is the core of leadership.

Sendjaya \& Cooper (2011) and Van Dierendock (2011) servant leadership or leadership serve as a form of contemporary leadership style, defined as a leadership practice that places the follower's interest above the personal interests of leaders. Servant leadership has a genuine commitment to their followers and will serve the needs of its followers.

\subsection{Employee Engagement}

In theory, Zinger (2012) defines employee engagement as an art and science to engage others, especially employees, in an effort to improve, retain, and transform work into a result. These employee engagements include strategy, role, performance, organization, community, relationships, customer, development, energy, and happiness.

Welch (1998) identifies the three best health-related measures of employee engagement programs that will affect first on employee engagement, both customer satisfaction, and the three cash flows. This identification shows that the success of employee engagement program is not only measured from within the organization that is successful implementation of employee engagement program and company cash flow. Employee engagement is measured by instruments adapted from Punitha and Rani (2013), which are attracted and inspired by their work, committed, and fascinated.

\subsection{Organizational Citizenship Behavior}

In the theory put forward by Organ (1988), organizational citizenship behavior is an individual behavior that is not directly or explicitly acknowledged by formal reward systems, and promotes efficient and effective functioning of organizations. Special behavior is the result of the perspective of functional behavior oriented to the status of "citizenship" in the organization.

Two main aspects of organizational citizenship behavior are mentioned in the study of Key Antecedence in organizational citizenship behavior (Khurana et al., 2014), namely OCB altruism and OCB adherence. OCB altruism is simply defined as a person's behavior of providing assistance to certain people. OCB adherence is generally a defined factor as one approaches the impersonal aspect of one's consciousness.

\subsection{Job Performance}

In theory proposed by Mototwidlo (2000) in Podsakoff, Mac Kenzie, Paine, \& Bachrach (2000), job performance is defined as the sum of individual behaviors over a period of time, contributing to the achievement of organizational goals. Griffin, Neal, \& Parker (2007) define it as increasing uncertainty and interdependence in work environments. It requires individuals to meet the requirements of formal job roles and exceed task responsibility to support the organization in a broader context so as to contribute to overall organizational performance.

\section{Methods}

This research using regression and correlation analysis, methods and will use survey design based on survey that aims to test the hypothesis. Hypotheses are made to look at the characteristics of a particular relationship, to see the relationships that affect and influence between the variables studied, to determine the differences between groups, or the interdependence of two or more factors in a situation.

Setting this research refers to research conducted by laub (2012) in his research on Assessing the servant organization development of the servant organizational leadership assessment (SOLA) instrument ", the level of intervention is correlative with the unit of analysis is the individual, the hotel employees in the organization Who has leader and character of servant leader organization. According to Hair, Black, Babin, and Anderson (2010), reliability test is a test performed to see the consistency of responsive ans wers. A series of measuring tools has a consistency when measurements with the measuring instrument are repeated. 


\subsection{Results of Verifikation Analysis}

Table 1. Model of Fit

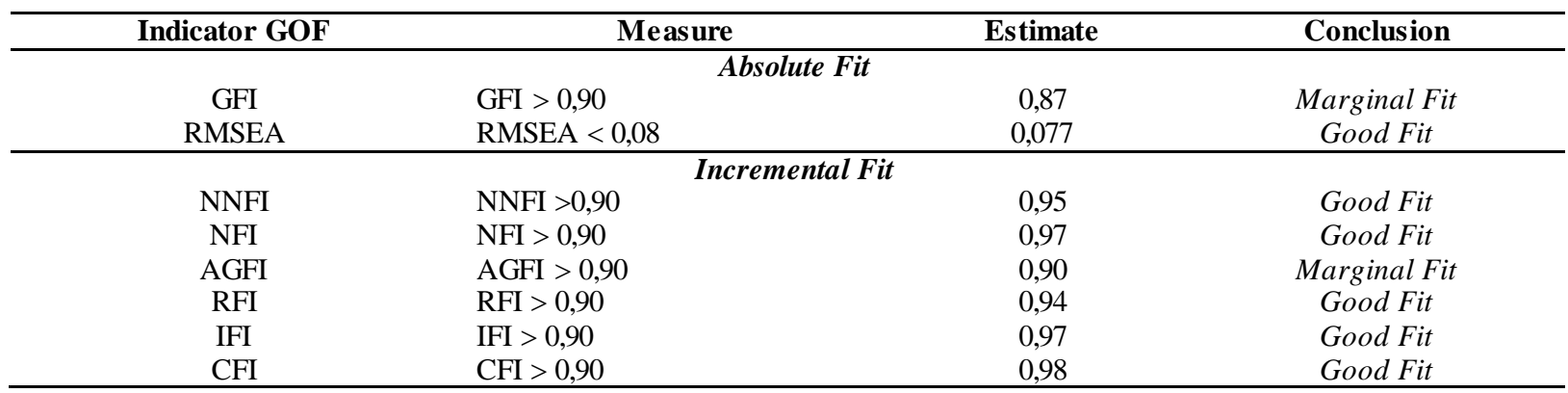

\subsection{Hypothesis Testing Results}

Table 2. Results Of Statistical Tests

\begin{tabular}{|c|c|c|c|c|c|c|}
\hline & Hypothesis & 1 & $\begin{array}{l}\text { Std. } \\
\text { Error }\end{array}$ & $\begin{array}{c}\mathbf{t}_{\text {value }} / \\
\mathbf{f}_{\text {value }}\end{array}$ & $\begin{array}{c}\text { Results } \\
\left(t_{\text {value }} \geq \mathbf{1 , 9 6 / f _ { \text { value } }} \geq\right. \\
\mathbf{3 , 8 4} \\
\end{array}$ & Conclusion \\
\hline \multirow{3}{*}{$\begin{array}{l}\mathrm{H} \\
\mathrm{H} \\
\mathrm{H}\end{array}$} & $\begin{array}{l}\text { Servant Leadership affects } \\
\text { Performance }\end{array}$ & 0,21 & 0,061 & 1,98 & Significance & $\begin{array}{c}\mathrm{H} 1 \\
\text { Accented }\end{array}$ \\
\hline & $\begin{array}{l}\text { Employee Engagement affects } \\
\text { Job Performance }\end{array}$ & 0,47 & 0,074 & 5,66 & Significance) & $\begin{array}{c}\text { H1 } \\
\text { Accepted }\end{array}$ \\
\hline & $\begin{array}{l}\text { Organizational Citizenship Behavior } \\
\text { affects } \\
\text { JobPerformance }\end{array}$ & 0,43 & 0,095 & 3,70 & Significance & $\begin{array}{c}\mathrm{H} 1 \\
\text { Accepted }\end{array}$ \\
\hline
\end{tabular}

\section{Servant Leadership is Positive and Significant to Job Performance}

The result of hypothesis testing shows that servant leadership has positive and significant influence on job performance. The results of this hypothesis test show that servant leadership measured by value people develop people, build community, display authentic, provide leadership, and shared leaderships partially affects the high performance employment of foreign bank employees in indonesia in the dimensions of task orientation, creativity and interpersonal relationships.

\section{Employee Engagement Positive and Significant impact on Job Performance}

The result of hypothesis we can describe based on the table -2 above that show employee Engagement has positive and significant effect on Job Performance. The results of this hypothesis test show that Employee Engagement as measured by the attracted and inspired by their work, committed and fascinated dimensions partially influences the high job performance of foreign bank employees in Indonesia in the dimensions of task orientation, creativity and interpersonal relationships.

\section{Organizational Citizenship is Positive and Significant to Job Performance}

The results of the hypothesis test showed that the Organizational Citizenship has positive and significant impact on Job Performance. The results of this hypothesis we can describe based on the table -2 above that show organizational citizenship behavior as measured by OCB Organization and OCB Individual dimensions partially influence on the high job performance of foreign bank employees in Indonesia both in the dimensions of task orientation, creativity and interpersonal relationships

Table 3. Influence of Servant Leadership, Employee Engagement and Organizational Citizenship to Job Performance

\begin{tabular}{lc}
\hline \multicolumn{1}{c}{ Direct Effect } & Total Effect \\
\hline Servant Leadership has positive effect and significance to Job Performance & 0,27 \\
Employee Engagement has positive effect and significance Job Performance & 0,44 \\
Organizational Citizenship has positive effect and significance to Job Performance & 0,39 \\
\hline
\end{tabular}

\section{Concl usion}

Servant leadership has a positive and significant effect on job performance with the effect of 0.27 . Based on the table -3 above, the strongest job performance indicator is indicated by the task orientation dimension. The weakest job performance indicator is shown interpersonal relationships dimension.

Employee engagement has a positive and significant effect on job performance with the effect of 0.44 . Based on the table -3 above, indicators the most strong employee engagement is indicated by the fascinated dimension and the weakest is shown the committed dimension. The strongest job performance indicator is indicated by the 
task-orientation dimension and the weakest is shown the interpersonal relationships dimension.

Organizational citizenship behavior has a positive and significant effect on job performance with the effect of 0.39 . Based on the table -3 above, the strongest organizational citizenship behavior indicator represented by affective commitment dimension and the weakest indicated is the normative commitment dimension. The strongest job performance indicator is indicated by the task-orientation dimension and the weakest is shown the interpersonal relationships dimension.

\section{Managerail Implication}

Servant leadership is a variable that is instrumental in improving job performance in Foreign Banks in Indonesia. Indicators of servant leadership that should be concerned and enhanced by management Foreign Banks in Indonesia are on indicator level of respect for others, listen, accept and not judge others, leading by example by modeling appropriate behavior, relate well to others, respect for diversity of people Etc., learning from employees at all levels and positions, maintaining integrity and trust, open to criticism and challenges from others, evaluating before blaming others, and giving hope to others.

Employee engagement is a very important variable in improving job performance in Foreign Banks in Indonesia. Indicators of employee engagement that must be considered and further enhanced by the management of Foreign Banks in Indonesia is indicator level of curiosity to work when I wake up, animates my work that I forget time, happy if it works in total, and the rate will be working for a long time with this company.

Organizational citizenship behavior is a very important variable in improving job performance in Foreign Banks in Indonesia. Organizational citizenship behavior indicators that must be considered and improved by the management of Foreign Banks in Indonesia are level indicators to have colleagues who have heavy workloads, willing to facilitate team work, and behave accordingly that they expect from others.

\section{References}

Griffin, M. A., Neal, A., \& Parker, S. K. (2007) A new model of work role performance: Positive behavior in uncertain and interdependent contexts. Academy of Management Journal, 50, 327-347. https://doi.org/10.5465/AMJ.2007.24634438

Hair, J. F. Jr., Black, W. C., Babin, B. J., \& Anderson, R. E. (2010). Multivariate Data Analysis. 7th Edition. Upoper Saddle River, NJ: Prentice Hall.

Kumar, R. (1999) Research Methodology: A step-by-step guide for beginners. London: Sage Publications.

Mahembe, B., \& Engelbrecht, A. S. (2013). The Relationship between Servant Leadership, Affective Team Commitment and Team Effectiveness. Journal of Human Resource Management, 11(4). https://doi.org/10.4102/sajhrm.v11i1.495

Mowday, R. T., Prter, L. W., \& Dan Steers, R. M. (1982). Employee Organization Lingkages: The Psychology of Commitment, Absenteeism and Turnover. London: Academic Press Inc.

Organ, D. W. (1982). Organizational citizenship behavior: the good soldier syndrome: Issues in organization and management series. Lexington, MA, England: Lexington Books.

Patterson, K. A. (2003). Servant leadership: A theoretical model. Paper presented at the Servant Leadership roundtable. Virginia Beach, VA: Regent University.

Punitha, K., \& Rani, S. A. (2015). A Study on Employee Engagement in Chettinad Cement Corporation Limited, Puliyur, Karur. International Journal of Management, 6(1), 630-639.

Sendjaya, S., \& dan Cooper, B. (2011). Servant Leadership Behavior Scale: A hierarchical model and test of construct validity. European Journal of Work and Organizational Psycology, 20(3), 416-436. https://doi.org/10.1080/13594321003590549

Sendjaya, S., Sarros, J. C., \& Santora, J. C. (2008). Defining nad Measuring Servant Leadership Behaviour in Organizations. Journal of Mangement Studies, 45-2(3), 402-424. https://doi.org/10.1111/j.1467-6486.2007.00761.x

Van Dierendonck, D., \& Nuijten, I. (2011). The Servant Leadership Survey: Development and Validation of a Multidimensional Measure. Journal of Business and Psychology, 26-3(9), 249-267. https://doi.org/10.1007/s10869-010-9194-1

Whetstone, J. T. (2002). Personalism and moral leadership: the sevant leader with a transforming vision. $A$ Business ethic European review, 11-4(10), 385-392. https://doi.org/10.1111/1467-8608.00298 
Wong, P. T. P., \& Davey, D. (2007). Best Practices in Servant Leadership. http://www.regent.edu/acad/global/publication/sl_proceedings/2007/wong-davey.pdf. (diakses 5 Maret 2016).

Zinger, D. (2012). 10 Building Blocks for Employee Engagement. USA: The Global and Mail.

\section{Copyrights}

Copyright for this article is retained by the author(s), with first publication rights granted to the journal.

This is an open-access article distributed under the terms and conditions of the Creative Commons Attribution license (http://creativecommons.org/licenses/by/4.0/). 